\title{
Internalisasi Nilai-nilai Karakter Peserta Didik dalam Pembelajaran Tahsin dan Tahfidzul Qur'an di SMA Darun Nasya Kabupaten Bandung Barat
}

\author{
Haris Fahrizal \& Muhammad Hijrah M Saway \\ UIN Sunan Gunung Djati Bandung, STAI Al-Falah Cicalengka Bandung \\ Harisfahrizal88@gmail.com,Sawayhijrah@staialfalah.ac.id
}

\begin{abstract}
Al-Qur'an as a holy book has an important role in the hearts of Muslims. A Muslim has an obligation to improve reading (Tahsin) and practice the messages contained. The Tabsin and Tabfidz learning programs which are currently widespread in schools and Islamic boarding schools foster a spirit of learning among the people. In particular, it motivates parents to send their children to schools that have tahfidzprograms. with the hope that the Tahsin and Tabfidz programs have a positive influence on the growth and development of students. This study aims to identify how the implementation of the tahsin and tahfidz.programs at SMA Darun Nasya with the hope of providing information on the internalization of character values. This type of research is field research with data collection techniques in the form of interviews, observations, and documentation. The results showed that there was a pattern of behavior change in students after participating in the tahsin and tabfidz learning programs.
\end{abstract}

Keywords : Character Values, Learning Tahsin and Tahfidz.

\begin{abstract}
Abstrak : Al-Qur'an sebagai kitab suci memiliki peran penting di hati umat Islam. Seorang muslim memiliki kewajiban memperbaiki bacaan (Tahsin) dan mengamalkan pesan-pesan yang terkandung. Program pembelajaran Tahsin dan tahfidz yang saat ini meluas di sekolah dan pesantren menumbuhkan semangat belajar kepada umat. Khususnya memotivasi para orang tua untuk memasukan anak-anak mereka ke sekolah yang memiliki program tahfidz. dengan harapan program Tahsin dan tahfidz memberikan pengaruh positif kepada tumbuh kembang peserta didik. Penelitian ini bertujuan mengidentifikasi bagaimana pelaksanaan program tahsin dan tahfidz di SMA Darun Nasya dengan harapan memberikan informasi adanya internalisasi nilai-nilai karakter. Jenis penelitian ini adalah penelitian lapangan dengan teknik pengumpulan data berupa wawancara, observasi, dan dokumentasi. Hasil penelitian menunjukkan bahwa terdapat pola perubahan perilaku pada peserta didik setelah mengikuti program pembelajaran tahsin dan tahfidz.
\end{abstract}

Kata Kunci : Nilai-nilai Karakter, Pembelajaran Tahsin dan Tahfidz

MANAZHIM : Jurnal Manajemen dan Ilmu Pendidikan

Volume 3, Nomor 2, Agustus 2021; 285-292

https:// ejournal.stitpn.ac.id/index.php/manazhim 


\section{PENDAHULUAN}

Pembangunan karakter bangsa adalah gagasan besar yang dicetuskan para pendiri bangsa dikarenakan bangsa ini terdiri dari suku-suku dan nuansa kedaerahan yang kental. Kesamaan pandangan tentang budaya dan karakter merupakan hal yang sangat dibutuhkan. ${ }^{1}$

Pembinaan karakter kepada peserta didik di sekolah sangatlah penting, karena sejalan dengan diutusnya nabi Muhammad shalallahu 'alaibi wasallam pernah berkata, “sesungguhnya Aku diutus kepada umat manusia untuk menyempurnakan akhlak." peserta didik yang berakhlak baik merupakan out put untuk mewujudkan generasi bangsa yang kokoh baik dalam pembangunan nasional dan bermasyarakat.

Banyak cara untuk menguatkan nilai karakter. Salah satu caranya adalah dengan menanamkan nilai-nilai karakter kepada peserta didik melalui proses pembelajar tahsin dan tahfidzul Qur'an. Sudah seharusnya sebagai seorang muslim memiliki rasa cinta kepada kitab sucinya agar terbangun interaksi yang baik dan intes. Dengan program tahsin dan tahfidzul Qur'an memungkinkan terjadinya interaksi antara peserta didik dan pendidik. Dalam interaksi tersebut terjadilah stimulus dan respond.

Perubahan dan kemampuan untuk berubah merupakan batasan dan makna yang terkandung dalam belajar. Karena dengan belajar manusia dapat berkembang lebih jauh daripada makhluk-makhluk lainnya, sehingga dapat memahami fungsinya sebagai khalifah. $^{2}$

Belajar dalam sudut pandang behavioristik adalah adanya perubahan tingkah laku sebagai akibat adanya interaksi antara stimulus (rangsangan) dan respon (tanggapan). Dapat difahami belajar merupakan bentuk perubahan yang dialami peserta didik dalam hal kemampuannya untuk bersikap. Dapat dikatakan teori behavioristik memandang belajar merupakan perubahan perilaku yang bisa diamati, diukur, dan dinilai secara konkret karena adanya interaksi antara stimulus dan respon. ${ }^{3}$

\footnotetext{
${ }^{1}$ Acetylena, Sita. 2018. Pendidikan Karakter Ki Hadjar Dewantara. Malang: madani

2 Syah, "Psikologi Belajar", (Bandung: Rajawali Pers, 2017), 23

${ }^{3}$ Wahab, "Psikologi Belajar", (Jakarta: Rajawali Pers, 2015), 44
} 
Karena tujuan dari pembelajaran tahfidzul qur'an ini adalah pembentukan kepribadian pada diri peserta didik yang dapat tercermin dalam tingkah laku dan kebiasaan dalam kehidupan sehari-hari, maka pembelajaran tahfidzul qur'an tidak hanya menjadi tanggung jawab guru tahfidz, tetapi dibutuhkan rekayasa lingkungan, seluruh komunitas sekolah dan lebih penting lagi adalah dukungan orang tua. Harapannya dalam proses pembelajaran tahfidzul qur'an adalah adanya perubahan perilaku dan kebiasaan peserta didik dalam aktivitas sehari-hari sebagai wujud dari aplikasi pengetahuan yang telah dipelajari.

\section{METODE PENELITIAN}

Penelitian ini dilakukan di SMA Darun Nasya Lembang Kab. Bandung Barat selain Lembaga formal peserta didik SMA Darun Nasya tinggal di asrama-asrma yang memiliki kegiatan agamis.

Adapun sumber yang dilakukan dalam teknik pengumpulan data dibagi menjadi dua sumber : Data Primer, data tersebut diperoleh berupa objek atau dokumen asli dari pelaku yang disebut dengan istilah first hand information mencakup segala informasi dan bahan materi yang berhubungan dengan internalisasi nilai-nilai karakter dan program tahfidz di SMA Darun Nasya. Data sekunder, data tambahan yang dibutuhkan mencangkup berbagi referensi literatur yang berkaitan dengan pembelajaran Tahsin dan tahfidz.

Beberapa metode yang digunakan dalam pengumpulan data dalam penelitian ini adalah: 1) Wawancara, metode ini digunakan untuk mendpatkan informasi lengkap berupa keterangan-keterangan secara lisan terkait perencanaan internalisasi nilai-nilai karakter. 2) Observasi, metode ini digunakan untuk mengamati secara langsung bagaimana internalisasi nilai-nilai karakter pada program pembelajaran Tahsin dan tahfidzul qur'an yang diteliti. 3) Dokumentasi, Teknik pengumpulan ini digunakan dengan mencari data-data yang relevan sebagai pembanding penguat penelitian ini. Data-daa yang diperoleh bersifat hal-hal berupa foto, catatan kaki, transkip, buku, surat kabar, majalah, artikel di internet dan lain sebagainya. ${ }^{4}$

\footnotetext{
${ }^{4}$ Zuhri, "Modernisasi Pendidikan Pesantren Al-Falah". (B. Agung, Interview)
} 
Teknik-teknik yang dilakukan dalam pengolahan di atas dilakukan dengan dua acara : 1) Deskripsi data, kegiatan ini dilakukan dengan menyusun data yang diperlukan dan kemudian dideskripsikan dengan uraian kata. 2) Analisa data, yaitu data yang sudah terkumpul dalam bentuk uraian kalimat tersebut dijelaskan dan dianalisis secara deskriptif mengenai terkaitan dengan data-data yang diperoleh dengan cara berpikir induktif yakni proses berpikir yang dimulai dengan pernyataan khusus ditarik kepada pernyataan umum berdasarkan dukungan data-data otentik.

\section{HASIL DAN PEMBAHASAN}

1. Internalisasi Nilai-Nilai Karakter

Internalisasi dari kata intern atau kata internal yang memiliki arti bagian dalam atau di dalam. Internalisasi adalah proses menanamkan sesuatu, keyakinan, sikap dan nilai-nilai sosial pada suatu individu ataupun kelompok yang akan membentuk pola pikirnya dalam melihat makna realitas pengalaman. Proses menanamkan yang dimaksud adalah tumbuh dari dalam diri seseorang sampai pada penghayatan suatu nilai.

Pengertian tentang internalisasi antara lain sebagai berikut: 1) Suatu proses dimana individu belajar dan diterima menjadi bagian, dan sekaligus mengikat diri kedalam nilai-nilai dan norma-norma sosial dari perilaku suatu masyarakat. ${ }^{5}$ 2) Proses dengan mana orientasi nilai budaya dan harapan pesan benar-benar disatukan dengan sistem kepribadian. 3) Internalisasi melibatkan sesuatu yakni ide, konsep dan Tindakan bergerak dari luar kesuatu tempat di dalam pikiran suatu kepribadian. ${ }^{6}$

Nilai dalam bahasa inggris value, berasal dari bahasa latin valere atau bahasa prancis kuno valoir. Seperti yang diketahui nilai adalah suatu yang berharga dan berguna bagi kehidupan manusia. Nilai amat bermakna bagi kehidupan manusia, nilai menjadi prinsip hidup, pedoman, penyelesaian konflik, memotivasi, dan mengarahkan pandangan hidup. Nilai adalah suatu tipe kepercayaan yang berada

${ }^{5}$ Kalidjernih, "Ragam Konsep dan Isu Kewarganeraraan” (Bandung: Widya Aksara Press, 2010)

'Johnson, “The Life of Samuel Johnson” (TLS, 1986), 87 
diruang lingkup sistem kepercayaan, dimana seseorang harus bertindak atau menghindari suatu tindakan mengenai sesuatu yang pantas atau tidak pantas dikerjakan ${ }^{7}$ Dengan demikian nilai adalah suatu sistem yang telah tertanam dan tumbuh dalam diri sebagai suatu kepercayaan dan pijakan dalam suatu tindakan yang sudah melekat pada diri manusia menjadi dasar bagi individua tau kelompok.

Karakter dalam bahasa Yunani character, dari charassein yang berarti membuat tajam ${ }^{8}$ Menurut KBBI karakter didefinisikan sebagai tabiat, sifat-sifat kejiwaan, akhlak atau budi pekerti yang membedakan seseorang dengan yang lainnya. Sedangkan kata berkarakter memiliki arti mempunyai tabiat, mempunyai karakter, memiliki watak. Karakter adalah cara bepikir dan berprilaku seseorang yang menjadi ciri khas dari setiap individu untuk hidup bekerjasama, baik dalam keluarga, masyarakat dan negara. ${ }^{9}$

Tujuan internalisasi nilai-nilai karakter, menanamkan nilai-nilai agama kepada peserta didik agar memiliki kepribadian berkakhlak mulia. Tidak hanya itu dengan nila-nilai agama harapannya agar kehidupan memiliki kebermaknaan. ${ }^{10}$ Harapan besar adalah dengan terbentuk kebiasaan baik dengan terus berinteraksi dengan kitab suci tumbuh kepribadian dan masyarakat mulia dan bertaqwa. Karena akhaq yang baik bersumber dari taqwa kepada Allah, semakin kuat ketaqwaan semakin kuat pula aklaknya. ${ }^{11}$

2. Pelaksanaan Program Tahsin dan Tahfidz di Darun Nasya Lembang

Proses pembelajaran tahfidz merupakan pembelajaran yang memiliki cara atau metode dalam mempelajari dan mendalami Al-Qur'an. membaca AlQur'an dengan melihat mushaf sebenarnya sudah memulai proses menghafal. Membaca ayat al-qur'an atau mendengarnya secara berulang-ulang itu menjadi modal awal proses menghafal Al-Qur'an.

7 Toha, “Kepemimpinan dalam Management” (Jakarta: Rajawali Pers, 2006), 67

${ }^{8}$ Majid \& Andayani, "Pendidikan Karakter Perspektif Islam”, (Bandung: Rosada, 2012)

${ }^{9}$ Muslich, "Pendidikan Karakter Menjawab tantangan Kritis Multimedia" (Jakarta: Bumi Aksara, 2011), 55

${ }^{10}$ Acetylena, "Pendidikan Karakter Ki Hadjar Dewantara” (Malang: Madani, 2018), 77

${ }^{11}$ Mahjuddin, “Akhlak Tasawuf”, (Jakarta: Kalam Mulia, 2010), 12 
Begitupun dalam proses pembelajaran tahfidz di SMA Darun Nasya Lembang diawali dengan melakukan pemetaan kualitas bacaan peserta didik atau seleksi masuk penempatan kelas dan peserta didik yang sudah mengikuti seleksi tersebut akan dikategorikan pada kelas a,b,c dan d. untuk kelas a, masuk kekelas iqro dan disebut pra tahfidz berarti nilainya dibawah 60 atau bacaannya kurang atau tidak bisa. Untuk kelas b, nilainya 70 yang bacaanya lumayan bisa atau terbata-bata itu menggunakan metode ummi. Kemudian untuk kelas c, yang bisa menghafal sendiri tetapi masih membutuhkan bimbingan dan nilainya 80 bacaanya lancar dan menyetorkan hafalanya setiap hari dan untuk kelas d, peserta didik sudah menghafal sendiri dan menyetorkan hafalanya satu minggu sekali serta membimbing adik kelasnya.

Dalam pelaksanaan pembelajaran tahfidz qur'an di SMA Darun-Nasya Lembang yaitu diawali dengan tahsin atau memperbaiki bacacaan peserta didik terlebih dahulu. Dan sesudah kegiatan tahsin dilanjut dengan menyetorkan hafalan yaitu menambah hafalan atau menambah ayat baru. Peserta didik setiap harinya akan menambah hafalan baru untuk disetorkan kepada pembimbing asrama atau kiyai. Dari wawancara yang telah peneliti lakukan dengan salah satu peserta didik tahfidz di SMA Darun Nasya Lembang, untuk waktu yang digunakan untuk menyetorkan hafalan adalah sesuai menyetorkan hafalan sepulang sekolah pada waktu siang hari jam 14.00 kepada asatidz. Tapi kebanyakan peserta didik lebih suka mengahafal diwaktu malam, karena cenderung lebih tenang dan sepi, karena di pagi dan siangnya para peserta didik harus melakukan aktivitas yang lumayan padat. Untuk itulah para peserta didik SMA Darun Nasya Lembang harus pandai mengatur waktu dengan baik.

Dilanjut dengan kegiatan muroja'ah dimana murojaah sudah menjadi suatu tradisi rutinan setiap hari bahkan bisa dibilang rutinan setiap waktu. Sebab terdengar lantunan ayat suci al-Qur'an tanpa henti disetiap sudut sekolah. Murojaah dilakukan setiap malam. Hal tersebut dilakukan lebih tepatnya sesudah shalat magrib dan berakhir ketika adzan isya' berkumandang. Para peserta didik memulai hafalan mereka dari juz 30 kemudian berlanjut kehalaman depan juz 1. 
Dan diakhiri dengan kegiatan yang terakhir yaitu ujian yang mana ujian tahfidz al-Qur'an ini merupakan salah satu upaya sekolah untuk menjadikan peserta didik seorang ulama yang intelek, tidak hanya seorang intelek yang tahu agama. Ujian tahfidz ini juga membangun budaya dan identitas. Dengan adanya program ini diharapkan peserta didik ketika lulus dari almamater SMA Darun Nasya Lembang memiliki setidaknya 5 juz hafalan al-Qur'an.

Tujuan diadakannya ujian tahfidz ini tidak hanya sekedar mempermudah para peserta didik dalam menghadapi ujian akhir semester, tapi juga menambah kuantitas hafalan ayat al-qur'an para peserta didik sekaligus kualitas hafalan alqur'an para peserta didik untuk menjadi peserta didik yang berpegang teguh terhadap al-qur'an.

Evaluasi pembelajaran tahfidzul quran di SMA Darun Nasya Lembang yaitu dengan memperhatikan empat kegiatan, yaitu: tahsin, menyetorkan hafalan, murojaah, dan ujian. Yang mana pendidik akan mengevaluasi para peserta didik dimulai dengan tahsin terlebih dahulu dengan memperhatikan bacaan serta hukum tajwidnya, dilanjut dengan menyetorkan hafalan kepada kiyai atau pembimbing, pendidik juga mengevaluasi para peserta didik dalam murojaah hafalan al-Qur'an dari juz 30 kemudian berlanjut kehalaman depan juz 1. serta evaluasi yang terakhir sekolah mengadakan ujian.

Adapun hasil wawancara kepadaa beberapa peserta didik dalam menjalani program tahfidzul qur'an yaitu menjalani berbagai aktivitas setiap hari, fokus terhadap program tahfidzul qur'an, dan bersyukur atas waktu yang termaksimalkan hanya untuk menghafal Al-Qur'an. Serta perubahan yang dirasakan selama mengikuti program tahfidzul qur'an, yaitu: lebih menekankan diri untuk menjaga dari maksiat, membuat mudah setiap apapun yang dihafal, sering membaca Al-Qur'an, hidup terasa lebih tertata, dan lebih giat beribadah wajib maupun sunnah. 


\section{KESIMPULAN}

Iternalisasi nilai-nilai karakter pada peserta didik memiliki ragam cara diantaranya dengan memberikan kegiatan positif seperti program tahsin dan tahfidzul qur'an. Karena bagaimanapun kebiasaan positif akan mengarahkan kepada keberhasilan internalisasi nilai-nilai karakter kepada peserta didik. SMA Darun Nasya Lembang Kab. Bandung Barat merencanakan program Tahsin dan tahfidzul qur'an agar program ini nenumbuhkan kecintaan kepada peserta didik yang mana harapannya adalah terinternalisasi nilai-nilai karakter.

\section{DAFTAR PUSTAKA}

Acetylena, Sita. 2018. Pendidikan Karakter Ki Hadjar Dewantara. Malang: madani Wahab, R. 2015. Psikologi Belajar. Jakarta: Rajawali Pers

Kalidjernih, F. 2010. Ragam Konsep dan Isu Kewarganeraraan. Bandung: Widya Aksara Press

Johnson, S. 1986. The Life of Samuel Johnson

Toha. 2006. Kepemimpinan dalam Management. Jakarta: Rajawali Pers

Majid \& Andayani. 2012. Pendidikan Karakter Perspektif Islam. Bandung: Rosada

Muslich. 2011. Pendidikan Karakter Menjawab tantangan Kritis Multimedia. Jakarta: Bumi Aksara

Syah, M. 2017. Psikologi Belajar. Bandung: Rajawali Pers

Mahjuddin. 2010. Akhlak Tasawuf. Jakarta: kalam Mulia

Zuhri, M. T. (2018, Desember 4). Modernisasi Pendidikan Pesantren Al-Falah. (B. Agung, Interview) 